\title{
Sodium- and Chloride-Dependent Creatine Transporter 1
}

National Cancer Institute

\section{Source}

National Cancer Institute. Sodium-and Chloride-Dependent Creatine Transporter 1. NCI

Thesaurus. Code C153432.

Sodium- and chloride-dependent creatine transporter 1 ( $635 \mathrm{aa}, \sim 71 \mathrm{kDa}$ ) is encoded by the human SLC6A8 gene. This protein plays a role in sodium and chloride ion-dependent transmembrane transport of creatine and phosphocreatine. 